\title{
Spectroscopy of olivine basalts using FieldSpec and ASTER data: A case study from Wadi Natash volcanic field, south Eastern Desert, Egypt
}

\author{
AHMED MADANI ${ }^{1,2}$ \\ ${ }^{1}$ Water Research Center, King Abdul Aziz University, P.O. Box 80200, Jeddah 21589, Saudi Arabia. \\ ${ }^{2}$ Department of Geology, Faculty of Science, Cairo University, Giza, Egypt. \\ e-mail: aamadani18@hotmail.com
}

\begin{abstract}
This paper aims at revealing the spectral characteristics of the olivine basalts exposed at Wadi Natash area, Egypt, using FieldSpec spectroradiometer. It also evaluates band ratios and fusion techniques for mapping purposes using ASTER data. Several volcanic episodes occurred during Early- to LateCretaceous are recorded in the study area. Early-Cretaceous olivine basalts are highly carbonated. LateCretaceous eruptions took place throughout several volcanic cones aligned in NW direction. Based on FieldSpec measurements and petrographic data, two groups of olivine basalt namely 'A' and 'B' are recognized. Fresh olivine basalt (group A) is characterized by low flat spectral profile with overall low reflectance values $(\sim 20 \%)$. Spectral profile of altered olivine basalt (group B) shows moderate reflectance values $(\sim 37 \%)$ with four little absorption features around the 1.10, 1.40, 2.00 and $2.35 \mu \mathrm{m}$ wavelength regions. These absorption features are attributed mainly to the presence of chlorite and carbonate alteration products as indicated by petrographic examination. ASTER false colour composite band ratio image (3/2:R, 8/1: $\mathrm{G}$ and 8/5:B) discriminates easily the fresh and altered basalts by deep blue and reddish blue colours respectively. Image fusion between previously mentioned FCC ratios image and high spatial resolution ASTER panchromatic image are carried out using brovey and HSV transformation methods. Visual and statistical assessment methods proved that HSV fusion image yields better image interpretability results compared to brovey image. It improves the spatial resolution of original FCC ratios image with acceptable spectral preservation. The present study proved the usefulness of FieldSpec spectral profiles and the processed ASTER data for discriminating different olivine basalt groups exposed at the study area.
\end{abstract}

\section{Introduction}

Phanerozoic volcanics in Egypt are sporadically distributed in both Eastern and Western Desert, as well as in the Sinai peninsula. Ten periods of volcanic activities are recognized during the Mesozoic, Tertiary and Quaternary times. During the Mesozoic time, Meneisy (1986) suggested three main phases of volcanic activity which are as follows: (1) Late Permian-Early Triassic (230 \pm
$10 \mathrm{Ma}),(2)$ Late Jurassic-Early Cretaceous (140 \pm $10 \mathrm{Ma}$ ), and (3) Late Cretaceous-Early Tertiary $(90 \pm 10 \mathrm{Ma})$. Wadi Natash volcanic field (figure 1), south Eastern Desert, Egypt represents one of the most important rift-related volcanics that took place during the Early- to Late-Cretaceous times prior to the Oligo-Miocene rift of the Red Sea. It lies midway between Kom Umbo city (Nile Valley) and Abu Ghosoun port (Red Sea coast). Several authors dealt with remote sensing,

Keywords. FieldSpec data; olivine basalts; ASTER data; band ratios; brovey-HSV techniques. 


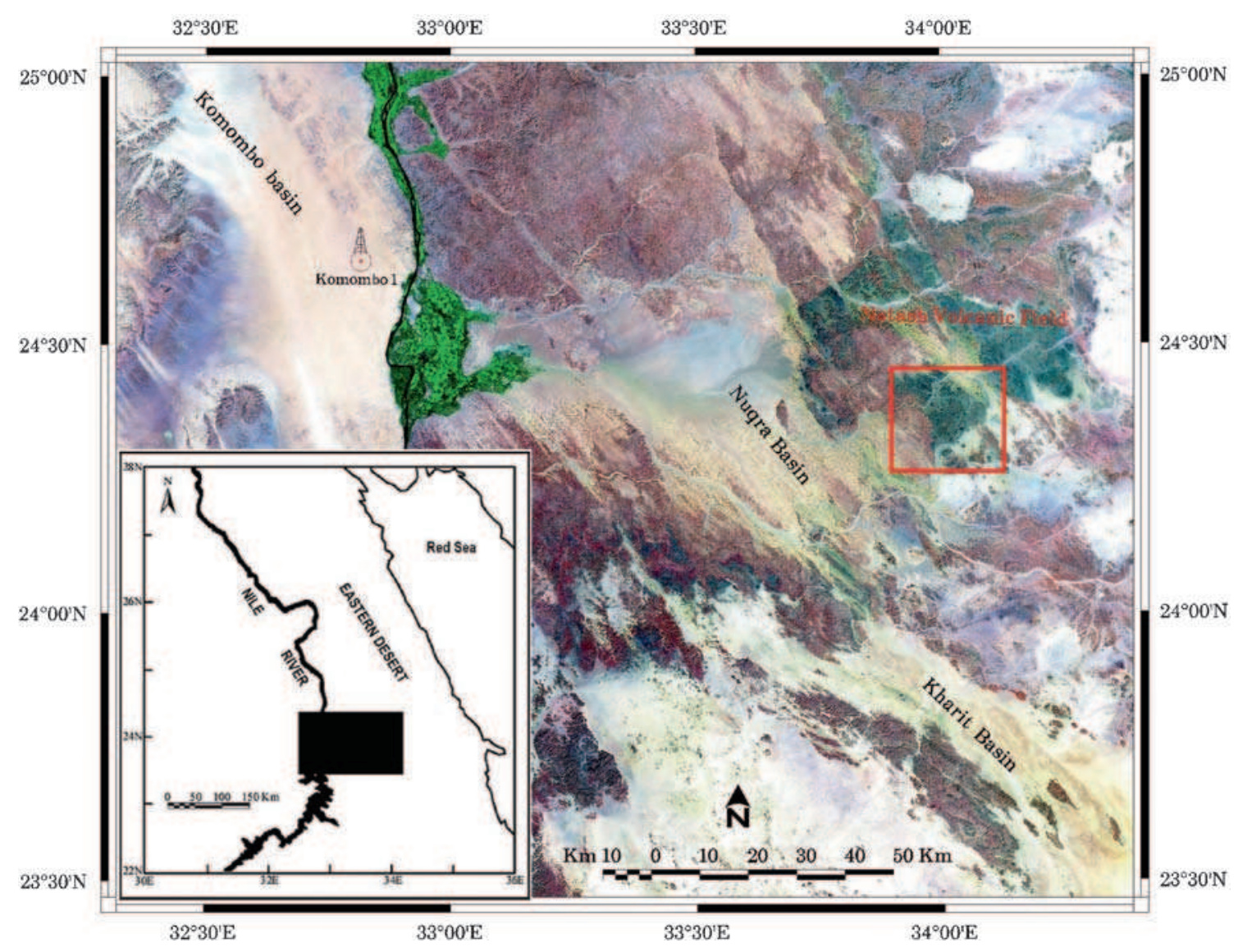

Figure 1. Location map of the study area. The inset represents the study area.

petrography and geochemistry of Wadi Natash volcanic field (Abu El-Gadayel 1974; Hashad et al. 1978; Hashad and El-Reedy 1979; Coulter 1981; Hubbard 1981; Crawford et al. 1984; Hubbard et al. 1987; Hashad 1994; Madani 2000, 2012). Madani (2000) studied in detail remote sensing, petrography and geochemistry of different volcanic rocks exposed at Wadi Natash area and he concluded that they are extruded at the eastern shoulder of the NW trending Komombo-NuqraKharit rift basin. Based on field data, Madani (2012) recognized two main volcanic episodes at Wadi Natash area (Jabal Maqtal) occurred during Late Jurassic-Early Cretaceous and Late Cretaceous times. The present study is conducted to reveal the spectral signatures of the olivine basalts exposed in Wadi Natash area (Jabal Maqtal) in relation to their mineralogy, and to apply the acquired knowledge to discriminate and delineate different volcanic groups using band ratios technique. Visual and statistical assessment of brovey and HSV image fusion techniques are also presented. Image fusion technique is a process of combining multi-spectral and panchromatic images to produce a new scene that has the best of original images. Many image fusion algorithms are developed to fuse high spectral resolution image with high spatial resolution panchromatic image such as brovey, IHS (Intensity-Hue-Saturation), PCA (Principal-Component-Analyses), HSV (HueSaturation-Value) and wavelet transform. Merging information from different imaging sensors involves two distinct steps (Chavez and Bowell 1988). First, the digital images from different sensors are geometrically registered to one another. Next, the information content (spatial and spectral) is mixed to generate a single image that contains the best of both sets. The merging of the three multispectral bands with another image channel is carried out by intensity substitution (Schettigara 1992).

\section{Stratigraphy and petrography of olivine basalts}

Many authors studied the stratigraphy, petrography and geochemistry of different volcanic rocks exposed at Wadi Natash area (Abu El-Gadayel 1974; Hashad et al. 1978; Coulter 1981; Madani 2000). Abu El-Gadayel (1974) recorded two main volcanic successions at Wadi Natash area. The first is made up of (from base to top) olivine basalt, andesite, mugearite and trachyte. The second includes (from base to top) olivine basalt, 
mugearite, benmorite, andesite, rhyodacite, trachyte, volcanic breccia and agglomerates. Coulter (1981) distinguished three distinct basalt flows separated by two beds of conglomerates with maximum thickness amounts to $258 \mathrm{~m}$. Hashad et al. (1978) concluded that Wadi Natash volcanic rocks developed from an olivine basalt parent magma, which by differentiation produced mugearite, benmorite and trachyte. Based on the processed Landsat ETM+ data and field observations, Madani (2000) recognized four main volcanic flows separated by three erosional surfaces. Three are basic (groups I, II and III) and the fourth has acidic composition (group IV). The volcanic sequence started from base by group I begins with coarse grained lithic crystal tuffs. The tuffs are overlain by greyish green trachytic basalt and followed by porphyritic olivine basalt. Group II started at the base by highly altered green mugearite grading to reddish, reddish grey amygdaloidal mugearite. Group III started with trachy basalt and is overlain by massive, black porphyritic basalt. Group IV started by fine grained green to red acidic tuffs followed by brown porphyritic rhyolite at the top. Field studies of the present work recorded two main types of olivine basalts exposed at the study area. The older olivine basalt is highly altered and amygdaloidal and contains ultramafic mantle xenoliths, whereas the younger type is extremely fresh and highly magnetic. Figure 2 shows the stratigraphic position of the fresh and altered basalts and their image signatures on band ratio images. The section starts at the base with $3 \mathrm{~m}$ red beds which are considered as paleosol. It is overlain by about $7 \mathrm{~m}$ greyish black basalt containing ultramafic mantle xenoliths (figure 3a). This basalt is highly altered and shows two perpendicular sets of fractures along which calcite and silica minerals and quartz are formed (figure $3 \mathrm{~b}$ ). It is overlain by $10 \mathrm{~m}$, highly altered, grayish green amygdaloidal basalt. The upper amygdaloidal basalt is followed by a surface of erosion leading to the formation of basal polymictic conglomerate that shows upward finning. This break is followed by about $7 \mathrm{~m}$ black basaltic eruption of high magnetic character and extremely fresh (Madani 2000).

The following paragraph describes in detail the petrographic characteristics of greyish black basalt, green amygdaloidal basalt and black basalt (Madani 2000). Greyish black basalt is characterized by highly altered olivine crystals, green spinel and clinopyroxenes (figure 4a) embedded within a fine-grained trachytic groundmass made of plagioclase, augite and opaques. Olivine phenocrysts are either extensively chloritized or partly replaced by carbonates due to injection of carbonate-rich

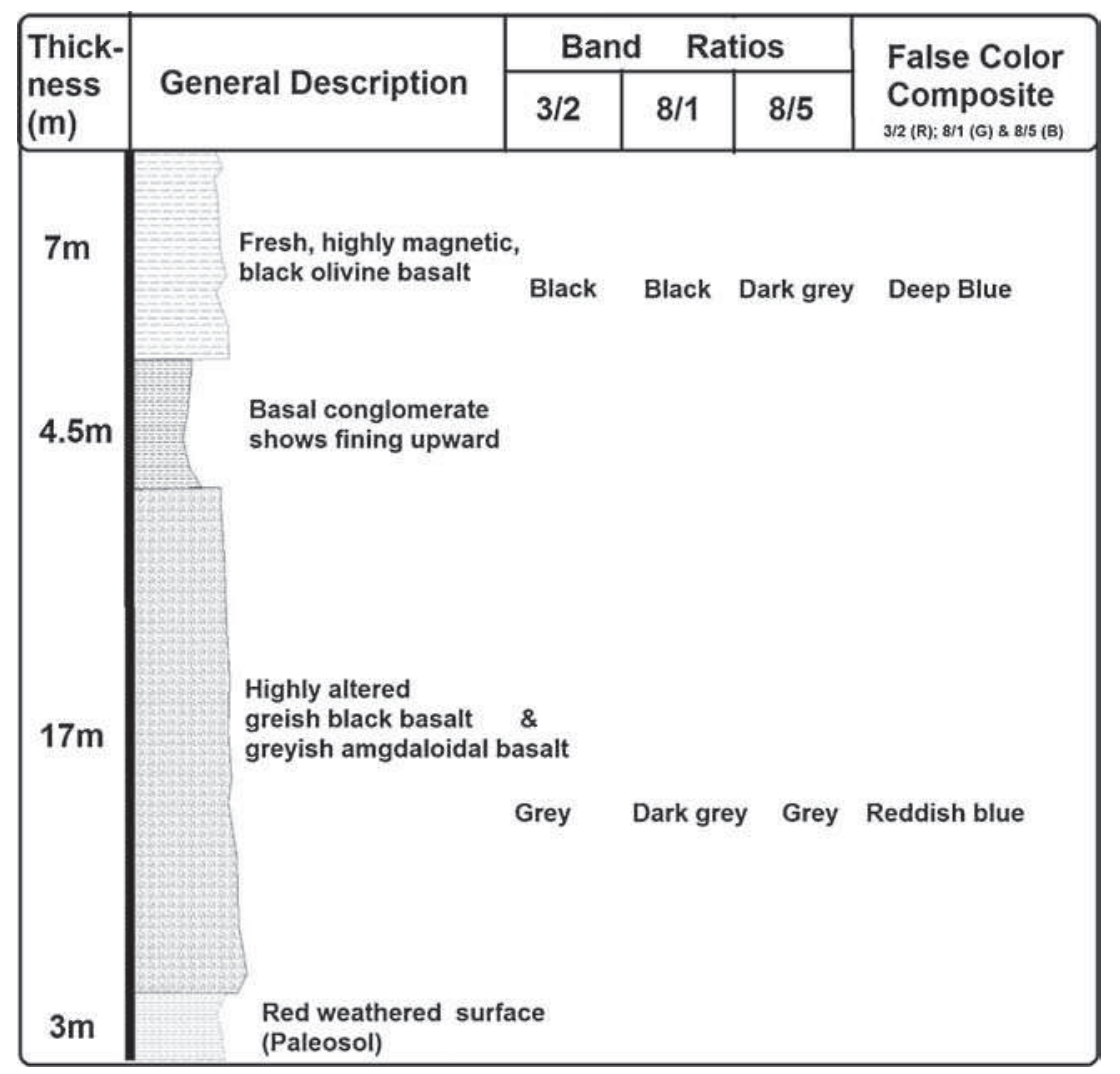

Figure 2. Stratigraphic position of fresh and altered basalts and their image signatures on band ratio images (modified after Madani 2012). 

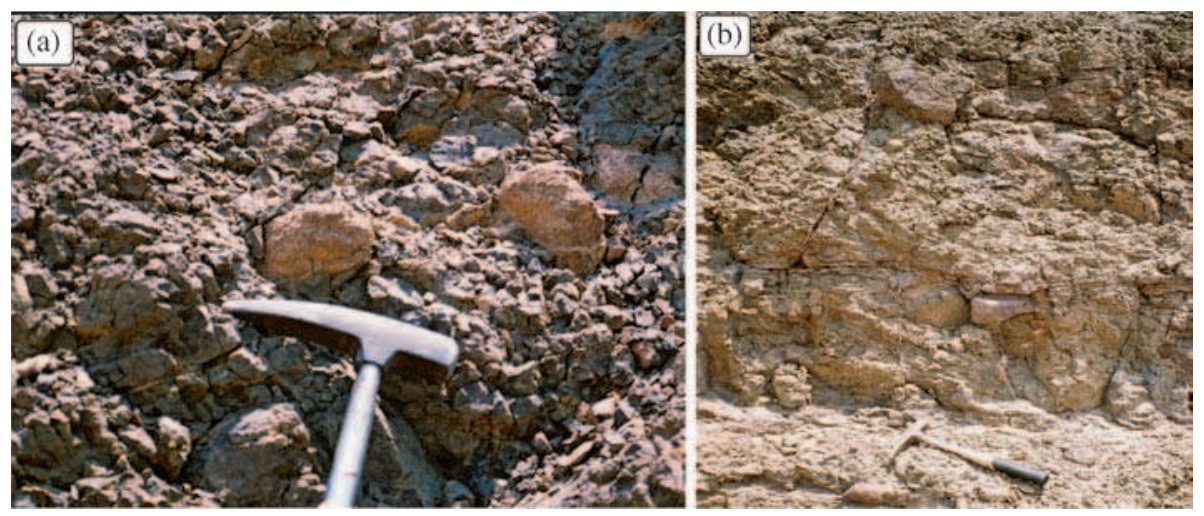

Figure 3. Field photos show that (a) greyish black basalt contain highly altered brown ultramafic mantle xenoliths, (b) highly altered basalt has fractures filled with calcite and silica minerals.
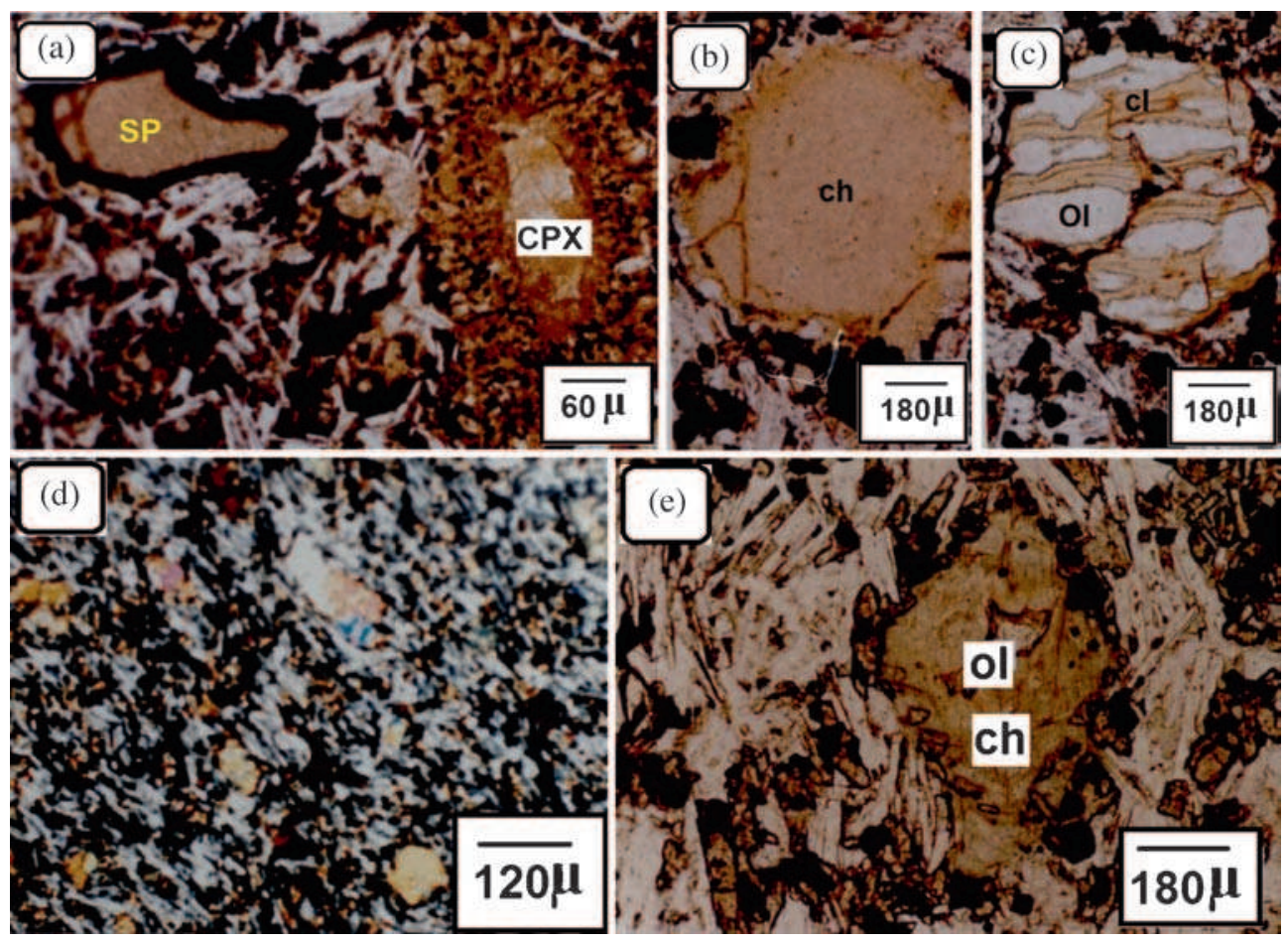

Figure 4. Photomicrographs of olivine basalts exposed at the study area. (a) Clinopyroxene (cpx) with fine opaques at its outer peripheries. Notice the presence of zoned brown spinel xenocryst, P.P.L. (b) Rounded vesicle filled by chlorite, P.P.L. (c) Chlorite replacing olivine phenocryst, P.P.L. (d) Small olivine phenocryst in black basalt showing flow texture, C.N. (e) Extensive replacement of olivine phenocryst (ol) by chlorite (ch). P.P.L.

fluid along cracks. Clinopyroxene is represented mainly by titanaugite occurring either as phenocrysts or in the groundmass. Greyish green amygdaloidal basalt is characterized by the presence of amygdales filled with chlorite (figure $4 \mathrm{~b}$ ), calcite, amorphous silica and brown glass. Two stages of crystallization are noticed. The first stage produced clinopyroxene and olivine phenocrysts, whereas the second stage produced fine-grained groundmass made up of plagioclase, clinopyroxene, opaques and apatite. Olivine is less predominant than clinopyroxene crystals. It shows alteration along their cracks and boundaries into chlorite (figure 4c) and Fe-oxides. Black olivine basalt exhibits flow texture (figure $4 \mathrm{~d}$ ) and is mainly composed of olivine phenocrysts embedded within a trachytic groundmass made up of augite, apatite, plagioclase and opaques. Chlorite and Feoxides are the main alteration products. Olivine is the predominant phenocrysts occurring either as bipyramidal crystals or in the form of anhedral rounded grains, often containing opaque inclusions. Some olivine crystals are totally altered to chlorite (figure 4e). 

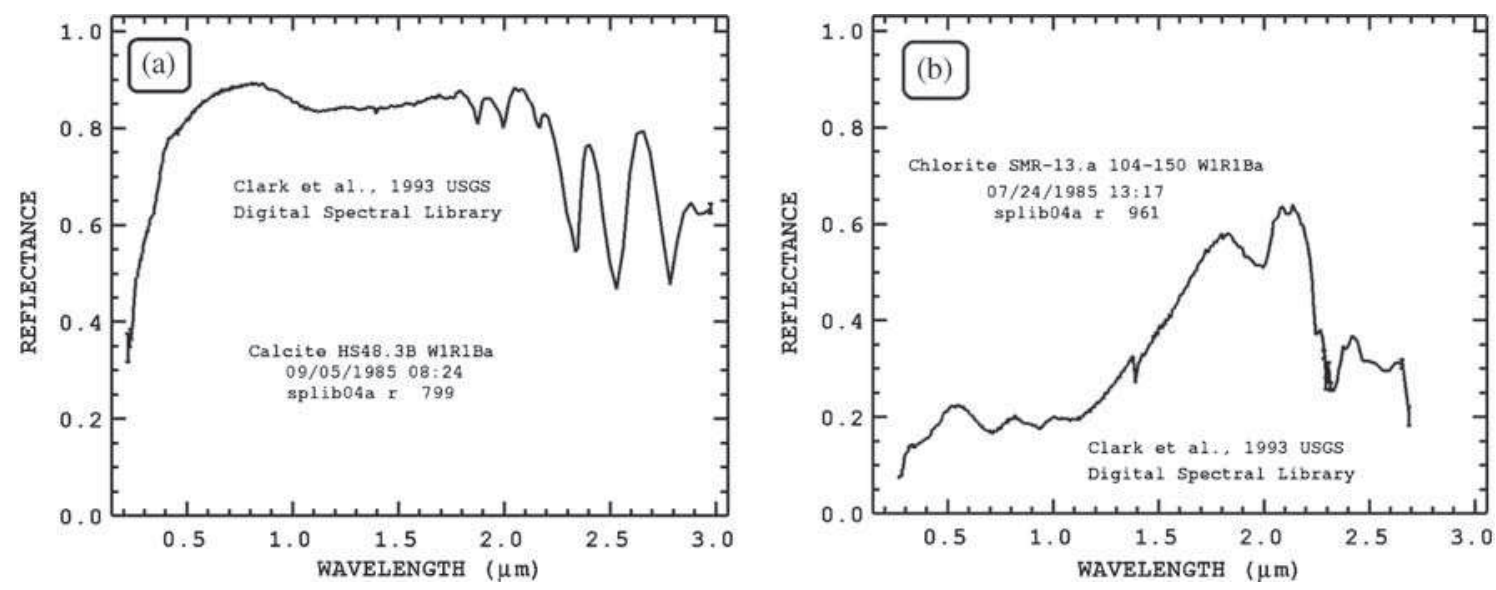

Figure 5. USGS spectral profiles for (a) calcite and (b) chlorite (Clark et al. 1993).

\section{Methodology}

\subsection{Spectral properties of olivine basalts using portable FieldSpec spectroradiometer}

Several authors dealt with the spectral characteristics of rocks and minerals (Hunt and Salisbury 1971; Adams 1974; Hunt 1977; Mackenzie et al. 1983; Gaffey 1984, 1986; Cloutis et al. 1986; King and Ridley 1987; Clark and Roush 1984; Cloutis 1985; Cloutis and Gaffey 1991a, b; Clark et al. 1990; Clark 1999; Sunshine and Pieters 1993, 1998; Klima et al. 2007, 2008, 2010; Madani 2011). Spectral characteristics of carbonate and chlorite minerals are dealt by many authors (Hunt and Salisbury 1971; Adams 1974; Hunt 1977; Mackenzie et al. 1983; Gaffey 1984, 1986; Madani 2011). Gaffey (1986) reported the presence of at least seven absorption features in 1.60-2.55 $\mu \mathrm{m}$ wavelength. Hunt and Salisbury (1971) reported five carbonate bands in this region $(1.90,2.00,2.16,2.35$ and $2.55 \mu \mathrm{m})$. Figure $5(\mathrm{a}$ and $\mathrm{b})$ shows the USGS spectral profiles of calcite and chlorite minerals after Clark et al. (1993). Madani (2011) studied in detail the spectral properties of the carbonatized ultramafic mantle xenoliths exposed at Jabal Al Maqtal strike-slip basin, south Eastern Desert, Egypt using portable ASD FieldSpec. He categorized two main groups of mantle xenoliths based on $\mathrm{Mn}$ and $\mathrm{Fe}$ contents and their absorption features at shorter wavelength regions. He attributed the absorption features around 1.80, 1.95, 2.00, 2.35, 2.4 and $2.5 \mu \mathrm{m}$ wavelength regions to the carbonate alterations. Madani and Harbi (2012) proved the usefulness of FieldSpec spectral profiles and the processed Landsat $\mathrm{ETM}^{+}$data for discriminating and delineating the mineralized tonalite-diorite intrusions exposed at Bughah gold mine area, Saudi Arabia. In the present study, the spectral data of two representative fresh and altered basaltic samples are collected using portable ASD FieldSpec
Table 1. Details of the ASD FieldSpec spectroradiometer.

\begin{tabular}{ll}
\hline Spectral range & $350-2500 \mathrm{~nm}$ \\
Detectors & VNIR $(350-1000 \mathrm{~nm})$ \\
& SWIR1 $(1000-1830 \mathrm{~nm})$ \\
& SWIR2 $(1830-2500 \mathrm{~nm})$ \\
Spectral resolution & $3 \mathrm{~nm}$ at $700 \mathrm{~nm}$ \\
& $10 \mathrm{~nm}$ at $1400 \mathrm{~nm}$ \\
& $10 \mathrm{~nm}$ at $2100 \mathrm{~nm}$ \\
Sampling interval & $1.4 \mathrm{~nm}$ for $350-1000 \mathrm{~nm}$ \\
& $2 \mathrm{~nm}$ for $1000-2500 \mathrm{~nm}$ \\
Field of view & $8,18,28$ degrees \\
\hline
\end{tabular}

spectroradiometer under suitable weather conditions. FieldSpec (table 1) is specifically designed for field environment to acquire visible near-infrared (VNIR) and short-wave infrared (SWIR) spectra in the $0.35-2.50 \mu \mathrm{m}$ wavelength spectral range (ASD 2007). Optimization and dark current collection are obtained before spectral data collection. Data measurements are resembled as 'RTRT' format in which ' $R$ ' refers to reference scan (spectralon) whereas, ' $\mathrm{T}$ ' refers to target scan. Figure 6 ( $\mathrm{a}$ and $\mathrm{b}$ ) shows FieldSpec spectral profiles of fresh and altered olivine basalts respectively. Low, nearly flat spectral profile (up to $\sim 20 \%$ ) in NIR and SWIR wavelength regions characterize the fresh basalt (group A). Moderate pronounced spectral reflectance values (up to $\sim 37 \%$ ) characterize the altered basalt (group B). The spectral profile of altered basalt exhibits broad absorption feature around $1.0 \mu \mathrm{m}$ wavelength region. This absorption feature is attributed to the presence of high percentage of ferric oxides in the groundmass as well as the presence of Fe-oxide alteration products of olivine crystals as indicated by petrographic examination. In addition, the spectral profile of the altered basaltic sample shows four little absorption features near $1.10,1.40,2.00$ and $2.35 \mu \mathrm{m}$ wavelength regions. The absorption features around 1.10 and $1.45 \mu \mathrm{m}$ 

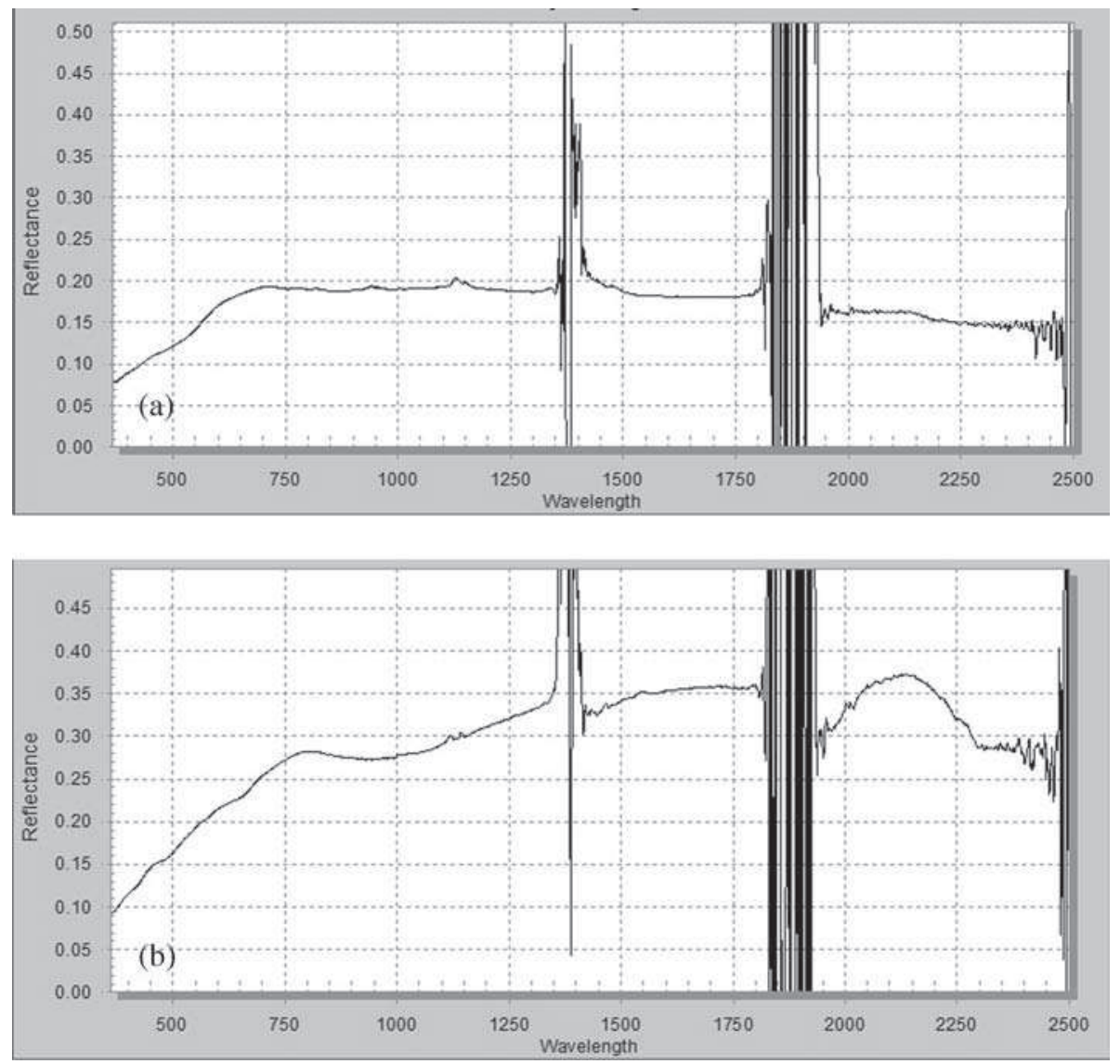

Figure 6. X-Y spectral plot of surface reflectance data for (a) fresh basalt and (b) altered basalt collected using FieldSpec instrument.

Table 2. Summary of the spectral properties of olivine basalt groups and related mineralogy.

\begin{tabular}{|c|c|c|c|}
\hline \multirow[b]{2}{*}{ Rock units } & \multicolumn{2}{|c|}{ Spectral properties } & \multirow[b]{2}{*}{ Mineralogical composition } \\
\hline & $\begin{array}{l}\text { ASD FieldSpec reflectance } \\
\text { profiles }\end{array}$ & $\begin{array}{l}\text { ASTER reflectance } \\
\text { profiles }\end{array}$ & \\
\hline $\begin{array}{l}\text { Fresh olivine } \\
\text { basalt }\end{array}$ & Low flat spectra. & $\begin{array}{l}\text { Low reflectance values } \\
\text { in VNIR region with } \\
\text { one absorption feature } \\
\text { around } 2.25 \mu \mathrm{m} \text {. }\end{array}$ & $\begin{array}{l}\text { Phenocrysts are represented by olivine and } \\
\text { pyroxene whereas groundmass is represented } \\
\text { by fine-grained laths of plagioclase, pyroxene } \\
\text { and opaques. }\end{array}$ \\
\hline $\begin{array}{l}\text { Altered olivine } \\
\text { basalt }\end{array}$ & $\begin{array}{l}\text { Broad absorption feature } \\
\text { around } 1 \mu \mathrm{m} \text { related to } \\
\text { Fe-alterations. Small } \\
\text { absorption features related } \\
\text { to calcite, silica and chlorite } \\
\text { alterations around } 1.10, \\
1.40,2.00 \text { and } 2.35 \mu \mathrm{m} \\
\text { wavelength regions. }\end{array}$ & $\begin{array}{l}\text { Two absorption features } \\
\text { around } 2.25 \text { and } 2.45 \mu \mathrm{m} \text {. }\end{array}$ & $\begin{array}{l}\text { Fe-oxides, chlorite, calcite and silica are main } \\
\text { alteration products. }\end{array}$ \\
\hline
\end{tabular}

wavelength regions are attributed to the presence of chlorite alteration. Whereas the absorption features around 2.00 and $2.35 \mu \mathrm{m}$ wavelength regions are attributed to the carbonate alterations. Table 2 shows the spectral characteristics of olivine basalt groups and their related mineralogy exposed in the study area.

\subsection{ASTER spectral profiles for olivine basalts}

ASTER is a joint project between United States and Japan. It captures moderate spatial and spectral resolution data in 14 bands (table 3), three of them cover VNIR wavelength region (0.52$0.86 \mu \mathrm{m})$, six SWIR bands cover 1.6-2.43 $\mu \mathrm{m}$ 
Table 3. ASTER data characteristics (modified after Fujisada 1995).

\begin{tabular}{llrlr}
\hline Characteristics & \multicolumn{2}{c}{ VNIR } & \multicolumn{2}{c}{ SWIR } \\
\hline Spectral range & Band 01 & $0.52-0.60 \mu \mathrm{m}$ & Band 04 & $1.60-1.70 \mu \mathrm{m}$ \\
& Band 02 & $0.63-0.69 \mu \mathrm{m}$ & Band 05 & $2.145-2.185 \mu \mathrm{m}$ \\
& Band 03N & $0.78-0.86 \mu \mathrm{m}$ & Band 06 & $2.185-2.225 \mu \mathrm{m}$ \\
& Band 03B & $0.78-0.86 \mu \mathrm{m}$ & Band 07 & $2.235-2.285 \mu \mathrm{m}$ \\
& & & Band 08 & $2.295-2.365 \mu \mathrm{m}$ \\
& & & Band 09 & $2.360-2.430 \mu \mathrm{m}$ \\
Ground resolution & \multirow{2}{*}{$15 \mathrm{~m}$} & & $30 \mathrm{~m}$ \\
Swath width & & \multicolumn{2}{l}{$60 \mathrm{~km}$} & \\
\hline
\end{tabular}
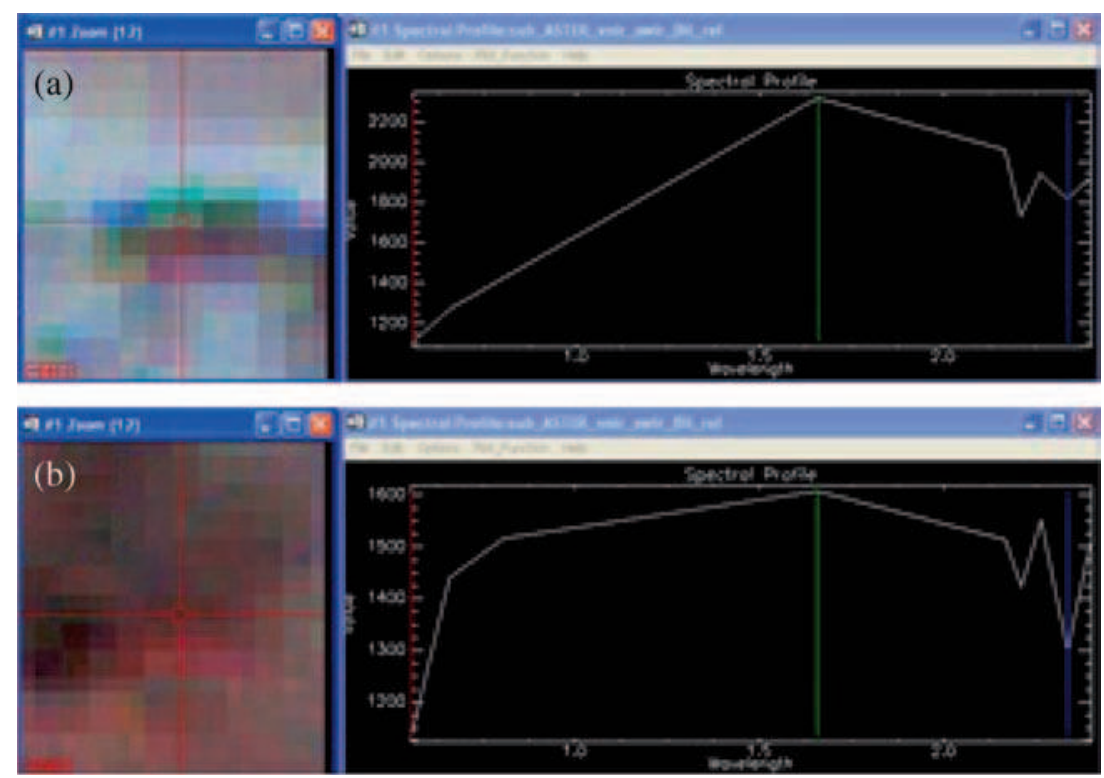

Figure 7. Spectral reflectance curves extracted from ASTER reflectance data for (a) fresh basalt and (b) altered basalt.

wavelength region and five bands in TIR between 8.125 and $11.65 \mu \mathrm{m}$. These bands have spatial resolution of 15, 30 and $90 \mathrm{~m}$, respectively. ASTER imagery level (1A) covered the study area is prepared and processed using ENVI v.5 package. Georeferencing of ASTER bands are carried out using the following projection parameters: UTM, WGS84 and zone 36 obtained from the header file. The resultant VNIR and SWIR images are combined, resampled to $30 \mathrm{~m}$ and converted from BSQ to BIL. FLAASH atmospheric correction model is used to obtain the surface reflectance image using scene center, flight date, ground elevation and flight time GMT parameters. The resultant surface reflectance images are used for subsequent processing techniques. ASTER surface reflectance images were used to generate spectral profiles for fresh and altered basalts. Figure $7(\mathrm{a}$ and $\mathrm{b})$ demonstrates the spectral reflectance curves of fresh and altered basalts. The spectral profile curve for fresh basalt shows absorption features near $2.25 \mu \mathrm{m}$. Two main absorption features near 2.25 and $2.45 \mu \mathrm{m}$ are observed on spectral profile curve of altered olivine basalt. These features may be related to carbonate alteration products.

\subsection{Band ratio technique}

Band ratio and image fusion (brovey and HSV) are the main techniques used in the present study. Band ratio can be simply generated by dividing the reflectance value of each pixel in one band by the reflectance value of the same pixel in another band (Drury 1993). In the present study, VNIR/SWIR ASTER bands are used to generate the ratio images using ENVI v.5 software. Visual inspection of the generated band ratio images revealed that $3 / 2,8 / 1$ and $8 / 5$ band ratio images (figure $8 \mathrm{a}, \mathrm{b}$ and c) are the most informative ratios for rock discrimination in the study area. Fresh basalts have black image signature on $3 / 2$ and $8 / 1$ band ratio images respectively. Whereas, they have dark grey image signature on $8 / 5$ band ratio. Altered basalts have dark grey and grey image signatures on $8 / 1,3 / 2$ and $8 / 5$ band ratios, respectively. The information contained in the above three band 

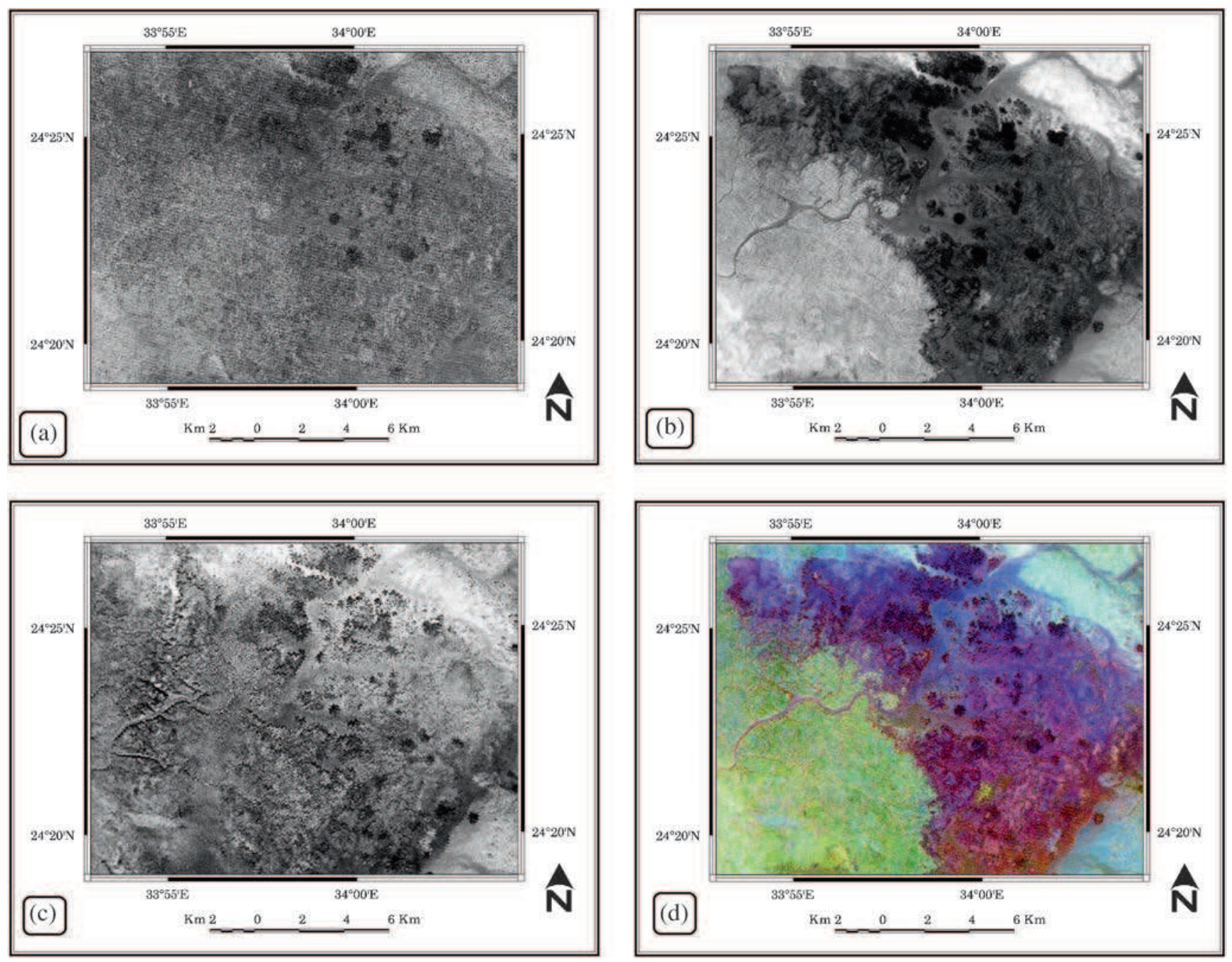

Figure 8. (a) $3 / 2$ band ratio image, (b) $8 / 1$ band ratio image, (c) $8 / 5$ band ratio image and (d) false colour composite band ratios image $3 / 2,8 / 1$ and $8 / 5$ in $\mathrm{RGB}$, respectively.

ratio images are integrated into one false colour composite ratio image $(3 / 2: \mathrm{R} ; 8 / 1: \mathrm{G}$ and $8 / 5: \mathrm{B}$; figure $8 \mathrm{~d}$ ). This $\mathrm{FCC}$ ratios image discriminates easily fresh and altered basalts by their deep blue and reddish blue colours, respectively.

\subsection{Fusion techniques}

Image fusion is the process of combining information from two or more images into a single composite image that is more informative and is more suitable for visual interpretation (Pohl and Van Genderen 1998). The fused images can provide information that sometimes cannot be observed in the individual input images. Several authors used image fusion techniques to improve the image interpretability of rock units. Madani (2003) merged a Landsat false colour composite ratio image $(5 / 7$, $3 / 1$ and $4 / 5$ in RGB) with the panchromatic high spatial resolution scanned aerial photograph using Hue, Saturation, Value (HSV) merger to produce
1:20,000 geological map for the hydrothermal alteration zones along the Haimur gold mine area, south Eastern Desert, Egypt.

In the present study, false colour composite ASTER ratios image $(3 / 2: \mathrm{R} ; 8 / 1 \mathrm{G}$ and $8 / 5: \mathrm{B})$ was fused with the high spatial resolution ASTER panchromatic image using brovey and HSV transformation methods. Figure 9(a and b) shows the results of brovey and HSV fused images respectively. Results of the two fusion transformation methods are assessed visually and statistically to select the most interpretable fused image used for mapping. The brovey transform is the simplest fusion technique in which the grey level (gl) values for each band are divided by the sum of all the colour layers (red, green and blue) and then multiply by the intensity layer (ASTER panchromatic image). The HSV colour fusion system is closely related to IHS fusion method, in which ' $\mathrm{H}$ ' is hue, ' $\mathrm{S}$ ' is saturation and ' $\mathrm{V}$ ' is value. During the fusion process, the component ' $\mathrm{V}$ ' is substituted 

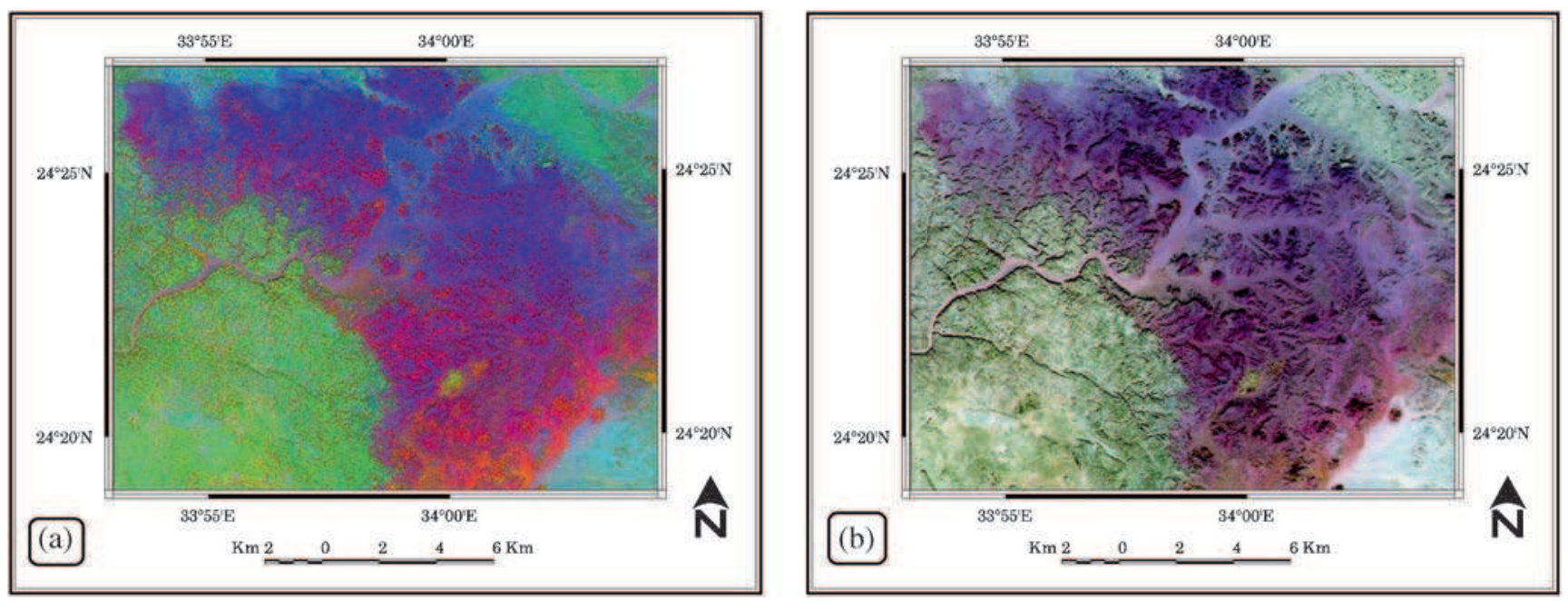

Figure 9. (a) Brovey fused image displayed in the band combination: red, green and blue. (b) HSV fused image for the study area displayed in the band combination: red, green and blue.

by a high spatial resolution ASTER panchromatic image. HSV colour fusion process was performed in three steps:

(1) transformation of the multispectral ratios image from RGB to HSV space,

(2) substitution of the intensity value from the high spatial resolution ASTER panchromatic band, and

(3) back transformation to RGB.

\section{Discussion}

Field visits to the study area revealed the presence of two main olivine basalt groups (fresh and altered). Samples from these groups were collected for FieldSpec measurements and petrographic study. Hunt et al. (1974) studied in detail the VNIR spectra of several basaltic types. They concluded that: (1) basalts are generally spectrally featureless because of extreme magnetic quenching. (2) Weak absorption features observed around 0.65 and $1.0 \mu \mathrm{m}$ are attributed to the ferric iron in augite and olivine. (3) Weak absorption features around 1.2 and $2.35 \mu \mathrm{m}$ are due to hydroxyl water band and calcite respectively. Petrographic investigation revealed the similarity in the mineralogical composition between the two basalt groups with some alteration products affecting the spectral profiles of both groups. Altered basalt has olivine, green spinel and clinopyroxenes as the main phenocrysts embedded within a fine-grained trachytic groundmass made of plagioclase, augite and opaques. Olivine phenocrysts are either extensively altered into Fe-oxides or chlorite along cracks or partly replaced by carbonates due to injection of carbonate-rich fluids. Clinopyroxene is represented mainly by titanaugite occurring either as phenocrysts or in the groundmass. Fresh olivine basalt exhibits flow texture and is mainly composed of olivine phenocrysts embedded within a trachytic groundmass made up of augite, apatite, plagioclase and opaques. Little alterations of chlorite and Feoxides are observed. The main mineralogical differences characterizing altered olivine basalt are: (1) presence of green spinel as phenocryst, (2) presence of carbonate and chlorite alterations, and (3) the presence of ferric iron in the groundmass and Feoxides alteration along olivine cracks. The opaque minerals greatly affect the FieldSpec spectral profile of fresh basalt (figure 10) in which they are: (1) lowering the overall reflectance values; (2) obscure the absorption features that characterized the spectral profile due to alteration products. The FieldSpec spectral profile of altered basalt (figure 10) is characterized by: (1) a broad absorption feature around $1.0 \mu \mathrm{m}$ wavelength region. This absorption feature is attributed to the presence of ferric iron in the groundmass and presence of Fe-oxide alteration products along olivine cracks as indicated by petrographic examination. Also this is supported by $\mathrm{Fe}_{2} \mathrm{O}_{3}$ content. It reaches 16.18 and $10.7 \mathrm{wt} \%$ in altered and fresh basaltic samples, respectively (Madani 2000). In addition, the altered basaltic sample shows four little absorption features near $1.10,1.40,2.00$ and $2.35 \mu \mathrm{m}$ wavelength regions. They are mainly attributed to the presence of chlorite and carbonate alteration products. Using observations from the spectral profiles, we assessed the validity of ASTER band ratios for discriminating the two basalt groups. $3 / 2,8 / 1$ and $8 / 5$ band ratio images are found visually the most informative ratios for discriminating both basalt groups. The false colour composite ratio image $(3 / 2: \mathrm{R} ; 8 / 1: \mathrm{G}$ and $8 / 5: \mathrm{B})$ discriminates easily the 


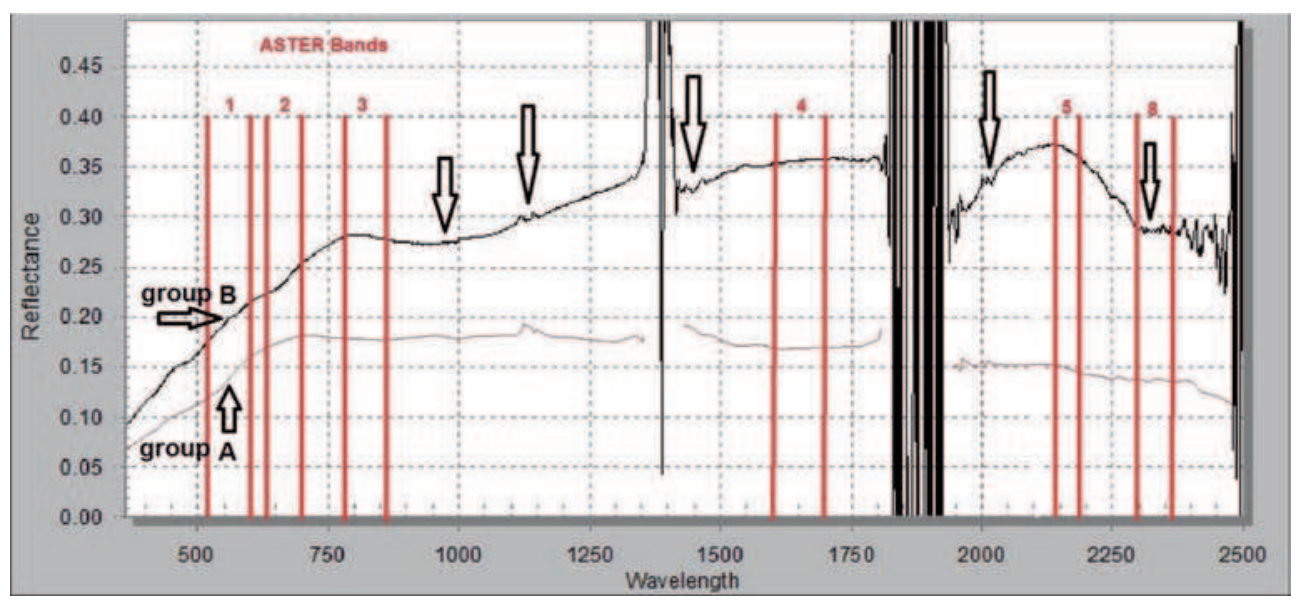

Figure 10. Compiled FieldSpec spectral profiles for basalt groups (A and B) exposed at Wadi Natash area.

Table 4. Statistical characteristics of the brovey and HSV fused images.

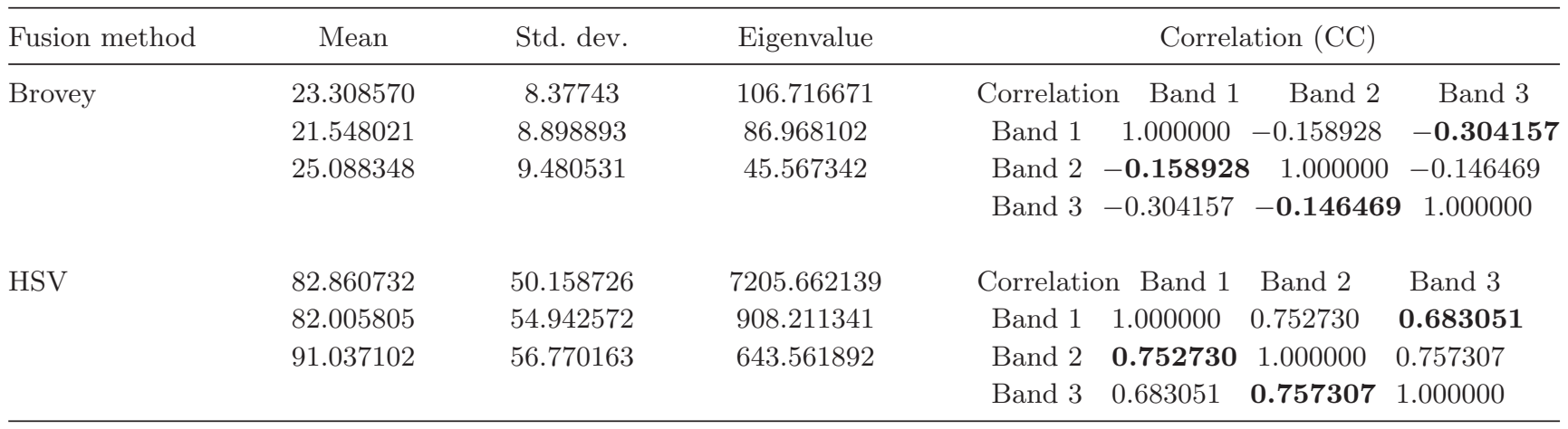

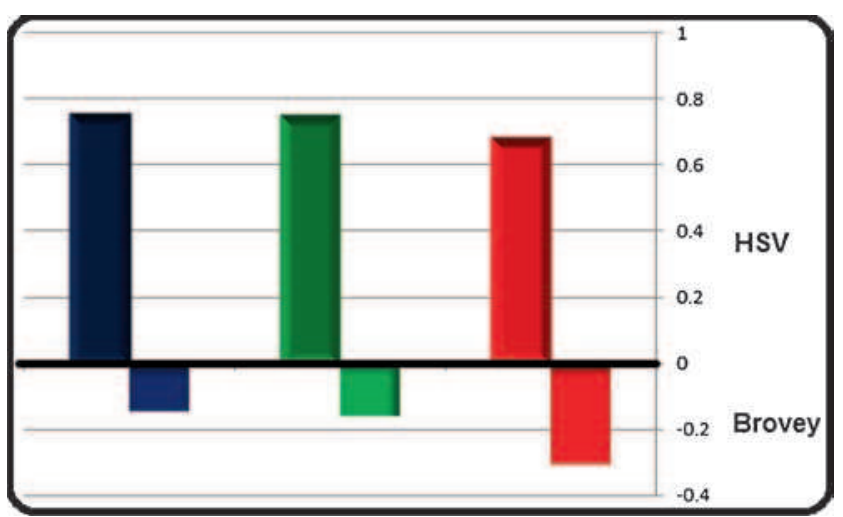

Figure 11. Correlation coefficient of brovey and HSV fused images.

fresh olivine basalt by deep blue colour and altered olivine basalt by reddish blue colour.

Several authors dealt with the assessment and evaluation of fusion techniques (Marcelino et al. 2009; Klonus and Ehlers 2009; Madani 2014). Visual and statistical assessment methods are used to ensure the improvement of spatial resolution and preservation of spectral characteristics of the original band ratios false colour composite image. Visual inspection of the brovey fused image (figure 9a) revealed no preservation of the spectral characteristics of the original FCC ratio image. These observations are confirmed statistically using correlation coefficient values (CC) (table 4 ). The correlation coefficient (CC) measures the correlation between the original and fused images. The ideal CC value is 1 . Table 4 shows that the values of the correlation coefficient for brovey image range between -0.146469 and -0.304157 (figure 11) which indicates large loss of spectral characteristics of the original ratios image during brovey transformation. Visual inspection of HSV fused image (figure 9b) revealed the following: (1) HSV improved the spatial resolution and maintained it all over the entire image. (2) There is no loss of spectral characteristics of rock units. These observations are confirmed statistically by $\mathrm{CC}$ values (table 4 ). The values of the correlation coefficient range between 0.683051 and 0.757307 (figure 11) which indicates good correlation to the original data. HSV fused image shows high correlation coefficient compared to broveyfused image and it gave best results for interpretability than brovey image. It preserves for large extent the spectral characteristics of the original FCC ratio image. 


\section{Conclusion}

The application of the FieldSpec measurements and the processed ASTER data clearly identifies and discriminates between the two groups of olivine basalts exposed at Wadi Natash area. The low general reflectance values of fresh olivine basalt (group 'A') are mainly due to the presence of high percentage of opaque minerals. The presence of broad absorption feature around $1.0 \mu \mathrm{m}$ wavelength region observed in altered basalt spectral profile is attributed to the presence of high percentage of ferric iron in the groundmass and presence of Fe-oxide alteration products along the cracks of olivine crystals. Also, altered basalt spectral profile shows four little absorption features near $1.10,1.40,2.00$ and $2.35 \mu \mathrm{m}$ wavelength regions. These absorption features are probably due to the presence of chlorite and carbonate alteration products. The present study proved the usefulness of band ratios and fusion techniques for discriminating different basalt groups exposed in the study area. FieldSpec profiles are utilized to understand the spectral characteristics of basalts and to select the optimum band ratios used for lithologic discrimination. Image fusion between $\mathrm{FCC}$ ratios image $(3 / 2$ : $\mathrm{R} ; 8 / 1: \mathrm{G}$ and $8 / 5$ : $\mathrm{B})$ and high spatial resolution ASTER panchromatic image is carried out using brovey and HSV transformation methods. Visual and statistical assessment of fusion methods revealed that HSV fused image gave better interpretability results. It improves spatial resolution and maintains, by a large extent, the spectral preservation of the original FCC ratios image.

\section{References}

Abu El-Gadayel A 1974 Contribution to the geology and geochemistry of Wadi Natash lave flows; M.Sc. thesis, Cairo University, Egypt.

Adams J B 1974 Visible and near-infrared diffuse reflectance spectra of pyroxenes as applies to remote sensing of solid objects in the solar system; J. Geophys. Res. 79 48294836.

ASD FieldSpec ${ }^{\circledR}$ 3, 2007 User Manual, ASD inc.

Chavez P S and Bowell J 1988 Comparison of the spectral information content of Landsat Thematic Mapper and SPOT for three different sites in the Phoenix, Arizona region; Photogramm. Eng. Remote Sens. 54(12) 16991708.

Clark R N 1999 Spectroscopy of rocks and minerals and principles of spectroscopy; In: Manual of Remote Sensing (ed.) Rencz A N, Remote Sensing for the Earth Sciences, John Wiley, New York, 3 3-58.

Clark R N and Roush T L 1984 Reflectance spectroscopy: Quantitative analysis techniques for remote sensing applications; J. Geophys. Res. 89 6329-6340.

Clark R N, King T V M, Klejwa M G A and Swayze G A 1990 High spectral resolution reflectance spectroscopy of minerals; J. Geophys. Res. 95(12) 653-680.
Clark R N, Swayze G A, Gallagher A J, King T V V and Calvin W M 1993 The U.S. Geological Survey, Digital Spectral Library: version 1: 0.2 to 3.0 microns: U.S. Geological Survey Open File Report 93-592, p. 1340.

Cloutis E A 1985 Interpretive Techniques for Reflectance Spectra of Mafic Silicates; M.S. thesis, University of Hawaii, Honolulu, Hawaii, USA.

Cloutis E A and Gaffey M J 1991a Pyroxene spectroscopy revisited - spectral compositional correlations and relationship to geothermometry; J. Geophys. Res. 96 22,80922,826

Cloutis E A and Gaffey M J 1991b Spectral compositional variations in the constituent minerals of mafic and ultra-mafic assemblages and remote sensing applications; Earth, Moon, Planets 53 11-53.

Cloutis E A, Gaffey M J and Reed K L 1986 Calibrations of phase abundance, composition, and particle size distribution for olivine-orthopyroxene mixtures from reflectance spectra; J. Geophys. Res. 91 11,641-11,653.

Coulter D H 1981 Petrology and stratigraphy of Wadi Natsh volcanics, Eastern Desert, Egypt; M.Sc. thesis, Bryn Mawr College, Bryn Mawr, USA.

Crawford W A, Coulter D H and Hubbard H B 1984 The areal distribution, stratigraphy and major elements chemistry of the Wadi Natash volcanic series, Eastern desert, Egypt; J. Afr. Earth Sci. 2(2) 119-128.

Drury S 1993 Image Interpretation in Geology, 2nd edn; Chapman and Hall, London.

Fujisada H 1995 Design and performance of ASTER instrument; Proceedings of SPIE, International Society for Optical Engineering, 2583 16-25.

Gaffey S 1984 Spectral reflectance of carbonate minerals and rocks in visible and near-infrared (0.35-2.55 lm): Application in carbonate mineralogy; Ph.D. thesis, Honolulu, University of Hawaii, 236p.

Gaffey S 1986 Spectral reflectance of carbonate minerals in the visible and near infrared $(035-2.5 \mathrm{~lm})$ : calcite, aragonite and dolomite; Am. Mineral. 71 151-162.

Hashad M 1994 Geochemical characteristics and petrogenesis of phonolitic trachytic plug associated with Wadi Natash volcanic rocks; M.E.R.C. Ain Shams Univ., Earth Sci. Ser 8 131-145.

Hashad A and El-Reedy 1979 Geochronology of the anorogenic alkalic rocks, south Eastern Desert, Egypt; Ann. Geol. Surv. Egypt 9 81-101.

Hashad A H, Hassan M A and Abuel Gadayel A A 1978 Trace element variations in the alkaline volcanics of Wadi Natash, Egypt; Bull. Fac. Sci. KSA 2 195-204.

Hubbard H B 1981 Geochemical evolution of Wadi Natash volcanic field, an alkaline basalt flood in the eastern desert of Egypt; M.Sc. thesis, Univ. South Carolina, USA.

Hunt G R, Salisbury J W and Lenhoff C J 1974 Visible and near infrared spectra of minerals and rocks: IX. Basic and ultrabasic igneous rocks; Mod. Geol. 5 15-22.

Hubbard H B, Wood L F and Rogers J W 1987 Possible hydration anomaly in the upper mantle prior to Red Sea rifting: Evidence from petrologic modeling of the Wadi Natash volcanic sequence of Eastern Desert, Egypt; Geol. Soc. Am. Bull. 98 92-98.

Hunt G 1977 Spectral signatures of particulate minerals in the visible and near-infrared; Geophysics 42 501-513.

Hunt G and Salisbury J 1971 Visible and near-infrared spectra of minerals and rocks: II. Carbonates; Mod. Geol. 2 $23-30$.

King T V V and Ridley W I 1987 Relation of spectroscopic reflectance of olivine to mineral chemistry and some remote sensing implications; J. Geophys. Res. 92 $11,457-11,469$. 
Klima R L, Pieters C M and Dyar M D 2007 Spectroscopy of synthetic $\mathrm{Mg}-\mathrm{Fe}$ pyroxenes I: Spin-allowed and spin-forbidden crystal field bands in the visible and near-infrared; Meteorit. Planet. Sci. 42 235-253.

Klima R L, Pieters C M and Dyar M D 2008 Characterization of the 1.2-lm M1 pyroxene band: Extracting cooling history from near-IR spectra of pyroxene-dominated rocks; Meteorit. Planet. Sci. 43 1591-1604.

Klima R L, Dyar M D and Pieters C M 2010 Near-infrared spectra of clinopyroxenes: Effects of calcium content and crystal structure; Meteorit. Planet. Sci. 46 379-395.

Klonus S and Ehlers M 2009 Performance of evaluation methods in image fusion; 12th International Conference on Information Fusion, USA, pp. 1409-1416.

Mackenzie F, Bischoff W, Bishop F, Loijens M, Schoonmaker J and Wollast R 1983 Magnesian calcites: Lowtemperature occurrences, solubility, and solid solution behavior; In: Carbonates: Mineralogy and Chemistry (ed.) Reeder R, Mineral. Soc. Am. Rev. Mineral. 11 97-144.

Madani A 2000 Geological studies and remote sensing applications on Wadi Natsh volcanics, Eastern Desert, Egypt; Ph.D. thesis, Fac. Sci., Cairo University, Egypt.

Madani A 2003 Evaluation of the Fusion of Landsat Thematic Mapper Imagery and Scanned Aerial Photograph for Mapping the Trachytic ring dykes, Wadi Natash area, South Eastern Desert, Egypt; 5th Int. Conf. on the Geol. of the Middle East, pp. 509-517.

Madani A 2011 Spectral properties of carbonatized ultramafic mantle xenoliths and their host olivine basalts, Jabal Al Maqtal basin, South Eastern Desert, Egypt, using ASD FieldSpec spectroradiometer; J. Remote Sens. Space Sci. 14 41-48.
Madani A 2012 Discrimination of Jurassic volcanicity in Strike-Slip basin, Jabal Al Maqtal Area, South Eastern Desert, Egypt, using ASTER and field data JAKU; Earth Sci. 23(2) 1-18.

Madani A 2014 Assessment and evaluation of band ratios, brovey and HSV techniques for lithologic discrimination and mapping using Landsat ETM+ and SPOT-5 data; Int. J. Geosci. 5 5-11.

Madani A and Harbi H 2012 Spectroscopy of the mineralized tonalite-diorite intrusions, Bulghah gold mine area, Saudi Arabia: Effects of opaques and alteration products on FieldSpec data; Ore Geol. Rev. 44 148-157.

Marcelino E, Formaggio A and Maeda E 2009 Landslide inventory using image fusion techniques in Brazil; Int. J. Appl. Earth Obs. Geo-infor. 11 181-191.

Meneisy M 1986 Mesozoic igneous activities in Egypt; Qatar Univ. Sci. Bull. 6 317-328.

Pohl A and Van Genderen L 1998 Review article multisensory image fusion in remote sensing: Concepts, methods and applications; Int. J. Remote Sens. 19(5) 823-854.

Schettigara V K 1992 A generalized component substitution technique for spatial enhancement of multispectral images using higher resolution data; Photogramm. Eng. Remote Sens. 58(5) 561-567.

Sunshine J M and Pieters C M 1993 Estimating modal abundances from the spectra of natural and laboratory pyroxene mixtures using the modified Gaussian model; J. Geophys. Res. 98 9075-9087.

Sunshine J M and Pieters C M 1998 Determining the composition of olivine from reflectance spectroscopy; J. Geophys. Res. 103 13,675-13,688. 